\author{
RAHMAN MOHAMMADI $^{\mathrm{a}}$ - ALI ASGHAR TALEBI ${ }^{\mathrm{a}}$ - YAGHOUB FATHIPOUR $^{\mathrm{a}}$ \\ FARZANEH KAZERANI ${ }^{\mathrm{b}}$ - REINOUD VAN DEN BROEK ${ }^{\mathrm{c}}$
}

\title{
REVIEW OF THE GENUS DIOCTRIA MEIGEN, 1803 (DIPTERA ASILIDAE) FROM IRAN, WITH FOUR NEW SPECIES RECORDS FOR THE IRANIAN FAUNA
}

\author{
${ }^{a}$ Department of Entomology, Faculty of Agriculture, Tarbiat Modares University, P.O. Box 14115-336, Tehran, Iran. \\ ${ }^{\mathrm{b}}$ Research Institute of Forests and Rangelands, Agricultural Research Education and Extension Organization \\ (AREEO), Tehran, I. R. Iran. \\ ' Waarneming.nl, Waarnemingen.be and Biodiversidad Virtual.org, Mariastraat 12, 5038SK Tilburg, The Netherlands. \\ Corresponding Author: Ali Asghar Talebi; talebia@modares.ac.ir
}

Mohammadi R., Talebi A.A., Fathipour Y., Kazerani F., Van Den Broek R. - Review of the genus Dioctria Meigen, 1803 (Diptera Asilidae) from Iran, with four new species records for the Iranian fauna.

Based on specimens collected, using sweeping nets and Malaise traps, from the East Azarbaijan, Guilan, Alborz and Mazandaran Provinces of Iran between May 2010 and September 2015, six species of the genus Dioctria Meigen, 1803 were collected. They were subsequently identified, and four species: Dioctria arnoldii V. Richter, 1964, D. humeralis Zeller, 1840, D. pilithorax V. Richter, 1980, and D. speculifrons Wiedemann, 1820, had not been previously recorded from Iran. Diagnostic characters and geographical distribution of the newly recorded species are provided. An illustrated key to all known Iranian Dioctria species is given.

KeY Words: Dioctria, Asilidae, Key, New records, Iran.

\section{INTRODUCTION}

The flies of the genus Dioctria Meigen, 1803 (Insecta: Diptera: Asilidae) are rather small to medium sized (6-20 $\mathrm{mm})$, nearly bare and often shiny black. The antennae are elongate, longer than the height of the eye and borne upon a protuberance which may be only slightly developed in some species. The fore tibia lacks an apical claw-like spur, the hind femora without strong bristles and the pulvilli are normally developed. Wings are relatively large, the 1st radial cell, all medial cells and posterior cubital cell are open (Richter, 1988). Among Asilidae, only the Dioctriinae possess an arched postmentum (DIKOw, 2009).

The genus Dioctria was placed within the tribe Dioctriini by Hull (1962) along with 14 genera of Dasypogoninae in which the 9th tergite of females lacks both acanthophorites and spines. PAPAVERO (1973) transferred the Dioctriini to the subfamily Stenopogoninae. LEHR (2001) lifted the tribe Dioctriini to the subfamily level. The Dioctriinae then comprised three tribes: Dioctriini, Echthodopini and Molobratiini (ADISOEMARTO and WOOD, 1975; LEHR, 2002). DIKOw (2009), using multiple character states, verified that Dioctriini and Echthodopini were indeed Dioctriinae, but Molobratiini was transferred back to the Dasypogoninae. With 90 species, Dioctria is the largest genus in the subfamily; 85 of these are known from the Palaearctic region (GELLER-GRIMM et al., 2015). Most of the species of the genus Dioctria can be found in the temperate belt and inhabit thick herbaceous grasslands, bushy thickets and wooded areas (LEHR, 1958).

Prior to this study, 11 Dioctria species had been reported from Iran. LEHR (1988) and LEHR et al. (2007) listed Dioctria lugens Loew, 1873, D. abdominalis Becker, 1923, D. atricapilla Meigen, 1804, D. rufonigra Theodor, 1980, D. striata Theodor, 1980 and D. valida Loew, 1856 from
Iran. GHAHARI et al. (2007) and HAYAT et al. (2008) added $D$. dispar Loew, 1871, D. gracilis Meigen, 1820, D. hyalipennis (Fabricius, 1794), D. flavipennis Meigen, 1820 and $D$. linearis (Fabricius, 1787) to the Iranian fauna.

This study was conducted to provide a comprehensive taxonomic treatment of Dioctria species known from Iran.

\section{MATERIALS AND METHODS}

Specimens of Dioctria were collected using sweeping nets and Malaise traps from May 2010 to September 2015 in East Azarbaijan, Guilan, Alborz and Mazandaran Provinces. The following references were used for identification of specimens and geographical distribution of species: ENGEL (1930); RICHTER (1960, 1964, 1988); LEHR (1988, 2001, 2002); GELlER-Grimm (2003) and GELLERGRIMM et al. (2015). Photos were taken using an Olympus TM SZX9 stereo-microscope equipped with a Sony TM digital camera. A series of 7-10 captured images were merged into a single in-focus image using the imagestacking software, Helicon Focus 6. The authors used Garmin, geko 301 to take GPS coordinates. The examined specimens are deposited in the Insect Collection of Department of Entomology, Tarbiat Modares University, Tehran, Iran (TMUC).

\section{RESULTS}

In this study, six species of the genus Dioctria Meigen, 1803 were collected and identified, of which four species including Dioctria arnoldii V. Richter, 1964, D. humeralis Zeller, 1840, D. pilithorax V. Richter, 1980, and D. speculifrons Wiedemann, 1820 are recorded from Iran for 
the first time. In addition, Dioctria atricapilla Meigen, 1804 and Dioctria linearis (Fabricius, 1787) are reported from the East Azarbaijan Province for the first time.

\section{LIST OF DIOCTRIA SPECIES KNOWN FROM IRAN}

Dioctria abdominalis Becker, 1923

Iranian records: Isfahan province (LEHR et al., 2007).

General distribution: Turkey (GELLER-GRIMm et al., 2015).

\section{Dioctria arnoldii V. Richter, 1964}

(Fig. I, 1-5)

Material examined: Guilan province (Roodsar, Rahim abad, Ziaz), 36 $52^{\prime} 34.44^{\prime \prime} \mathrm{N}, 50^{\circ} 13^{\prime} 17.40^{\prime \prime} \mathrm{E}, 537 \mathrm{~m}, 15$ June 2010, $20^{\lambda}$ (photographed specimen); Guilan province (Roodsar, Rahim abad, Ghazichak), 36 45'52.62" N, $50^{\circ} 20^{\prime} 01.08^{\prime \prime} \mathrm{E}, 1787 \mathrm{~m}, 5$ July 2010,2 웅 Guilan province (Roodsar, Rahim abad, Orkom), 36 $45^{\prime} 44.34^{\prime \prime} \mathrm{N}$, $50^{\circ} 18^{\prime} 11.88^{\prime \prime} \mathrm{E}, 1201 \mathrm{~m}, 8$ June 2010, 1 ㅇ.

Iranian records: Guilan province (current study), new record for Iran.

General distribution: Armenia, Azerbaijan, Georgia (LEHR, 1988, 2002).

Diagnostic characters: Large black species (12-15 mm) with a black stripe on the face. Facial tomentum only present along eye margins leaving a shiny black stripe on the face between mystax and frontal tubercle (Fig. I, 1); scape about 1.5x to $2 x$ pedicel; mystax black (Fig. I, 3). Thorax black, scutum shiny black without tomentum; stripe of pale tomentum on pleura complete (Fig. I, 2); coxae black. Legs somewhat variable, usually front and mid- dle femora yellowish-red with a black posterior side, hind femur black with a narrow red apex, front and middle tibiae yellowishred with a black apex, hind tibia black with a red base, all tarsi black (Fig. I, 1). Wings faintly infuscate (Fig. I, 5), darker in basal part, abdomen shiny black (Fig. I, 4).

Dioctria atricapilla Meigen, 1804

(Fig. II, 1-3)

Material examined: East Azarbaijan province, Arasbaran

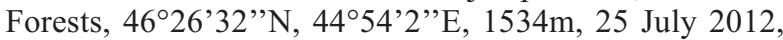
$1 \uparrow, 3 \widehat{\circlearrowleft}$ (photographed specimen).

Iranian records: Golestan province (LEHR et al., 2007), East Azarbaijan province (current study).

General distribution: Austria, Belgium, Bulgaria, Republic of Belarus, Corsica, Denmark, Estonia, Finland, France, Germany, Hungary, Italy, Kazakhstan, Latvia, Lithuania, Luxembourg, Moldavia, Mongolia, Netherlands, Poland, Romania, Russia, Sweden, Switzerland, Turkey, Ukraine, United Kingdom (GELLER-GRIMM et al., 2015)

Dioctria dispar Loew, 1871

Iranian records: Guilan province (HAYAT et al., 2008).

General distribution: Russia, Kyrgyzstan, Tajikistan, Uzbekistan (GELLER-GRIMM et al., 2015).

Dioctria flavipennis Meigen, 1820

Iranian records: Provinces: Guilan (HAYAT et al., 2008); Isfahan (GHAHARI et al., 2007); Mazandaran (GHAHARI et al., 2007; HAYAT et al., 2008).
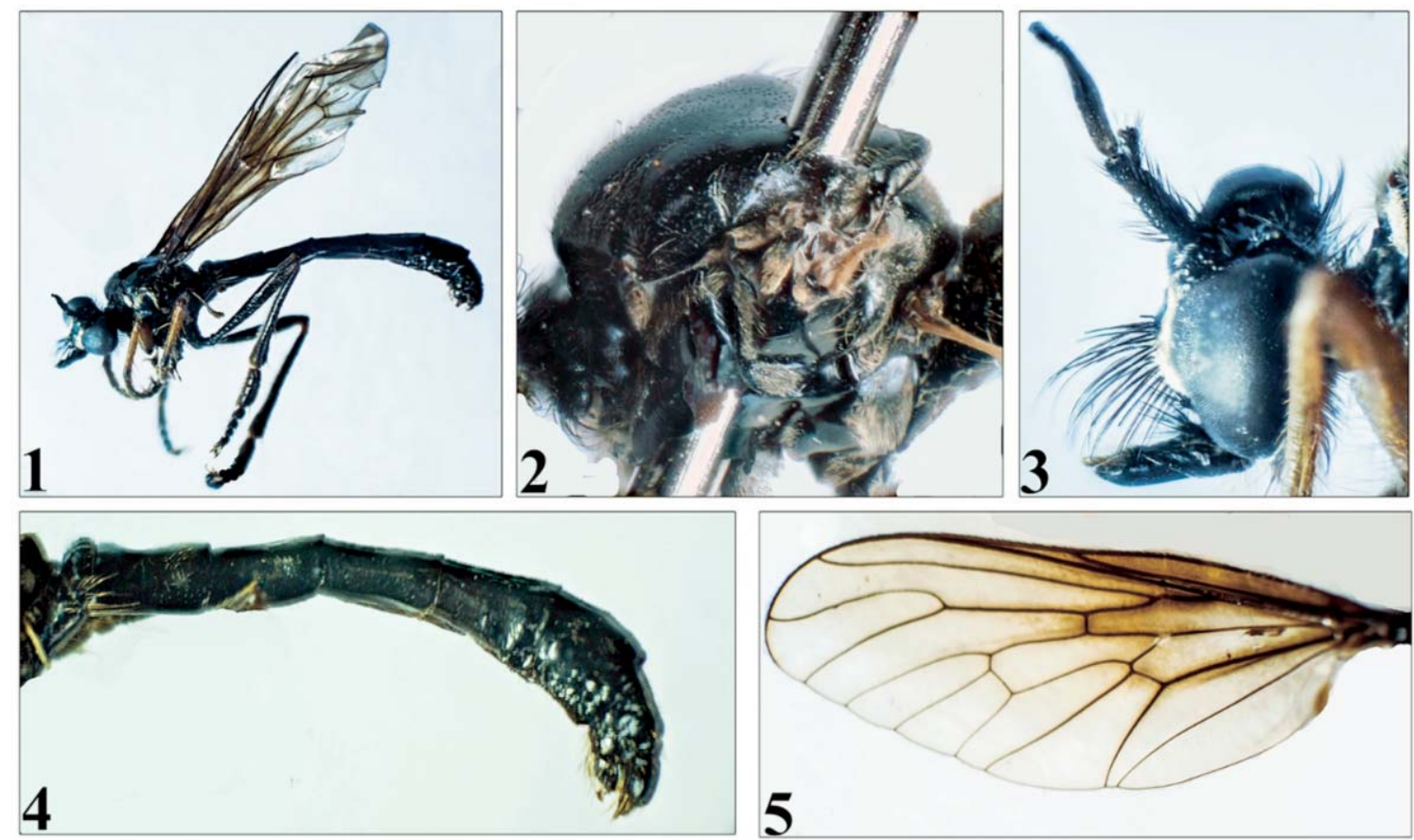

Fig. I - Dioctria arnoldii V. Richter, 1964 1-5: male. 1. General habitus, lateral view; 2. Thorax, lateral view; 3. Head, lateral view; 4. Abdomen, lateral view; 5. Wing, dorsal view. 

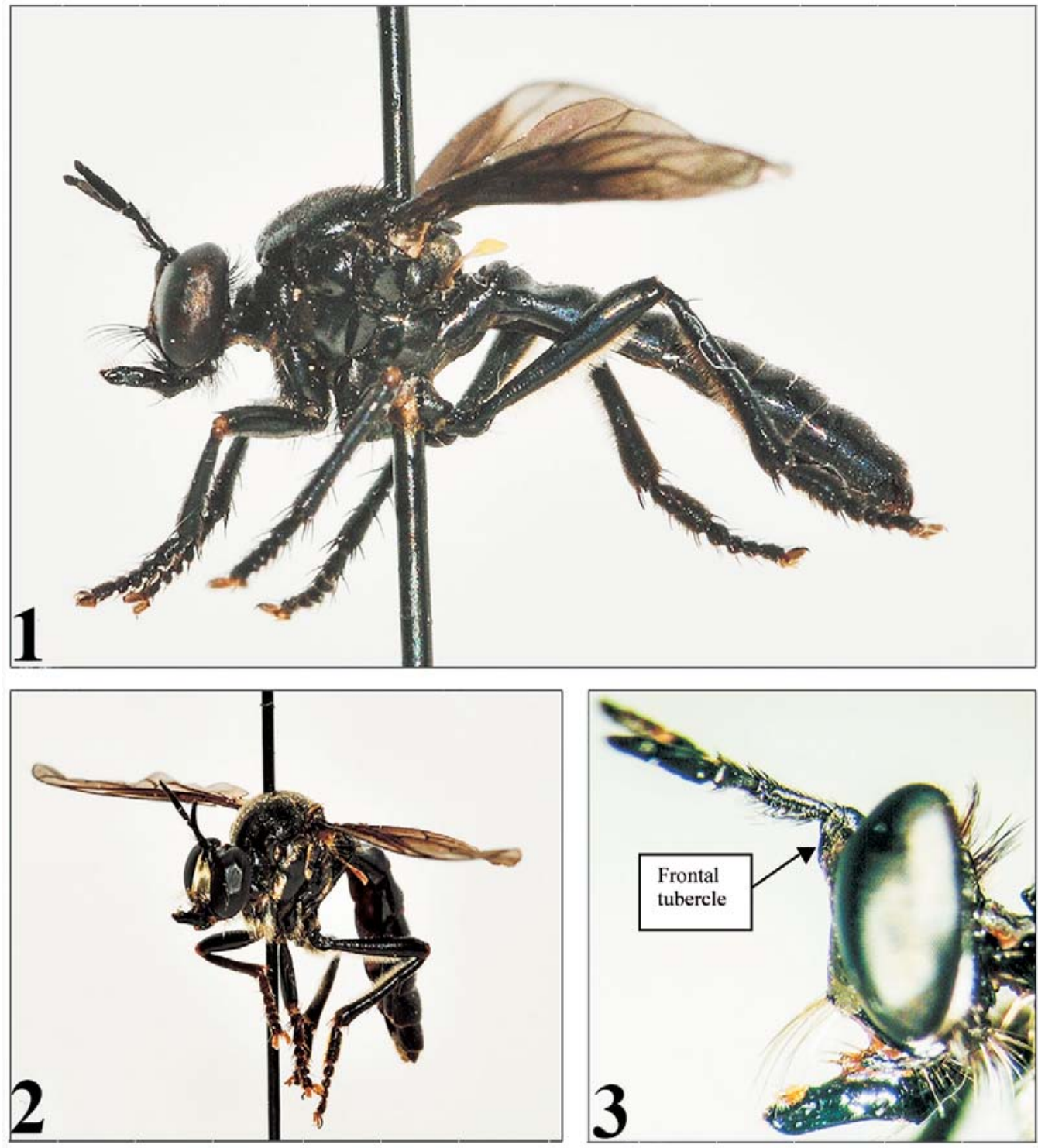

Fig. II - Dioctria atricapilla Meigen, 1804 1-3: male. 1. General habitus, lateral view; 2. General habitus, laterofrontal; 3. Head, lateral view.

General distribution: Austria, Bulgaria, Republic of Belarus, China, Czech Republic, Estonia, France, Germany, Great Britain, Hungary, Kazakhstan, Kyrgyzstan, Latvia, Lithuania, Moldavia, Poland, Romania, Russia, Tajikistan, Turkey, Turkmenistan, Ukraine, Uzbekistan, West Siberia (GELLER-GRIMM et al., 2015).

\section{Dioctria gracilis Meigen, 1820}

Iranian records: Southern Khorasan province (HAYAT et al., 2008).

General distribution: Algeria, France, Germany, Italy, Sardinia, Switzerland, Turkey (GELLER-Grimm et al., 2015).

\section{Dioctria humeralis Zeller, 1840}

(Fig. III, 1-4)

Material examined: Guilan province (Roodsar, Rahim abad, Ziaz), 36 $52^{\prime} 27.18^{\prime \prime}$ N, 50¹3'24.78" E, 490 m, 4 June 2010, 1 ( (photographed specimen); Mazandaran province
(Tangheh vaz), 36²1'55” N, 5206’10”E, 692 m, 20 July 2012,2ㅇ.

Iranian records: Guilan and Mazandaran provinces (current study), new record for Iran.

General distribution: Bulgaria, Czech Republic, Germany, France, Hungary, Poland, former Yugoslavia, Kazakhstan, China, Hungary, Slovakia (Lehr, 1988; GELLER-Grimm et al., 2015).

Diagnostic characters: A small species $(7-8 \mathrm{~mm})$ with reddish-brown parts on thorax. Shiny tomentum on face, golden yellow; mystax yellow; scape about $2 x$ pedicel. Thorax black, postpronotal lobes, often postalar calli and part of scutellum reddish-brown (Fig. III, 2). Scutum with the typical pattern of tomentum leaving the two para median stripes and the lateral spots black; stripe of pale tomentum on pleura complete and yellowish in colour; coxae yellow. Legs almost entirely yellow including tarsi. Wings almost hyaline (Fig. III, 1). 

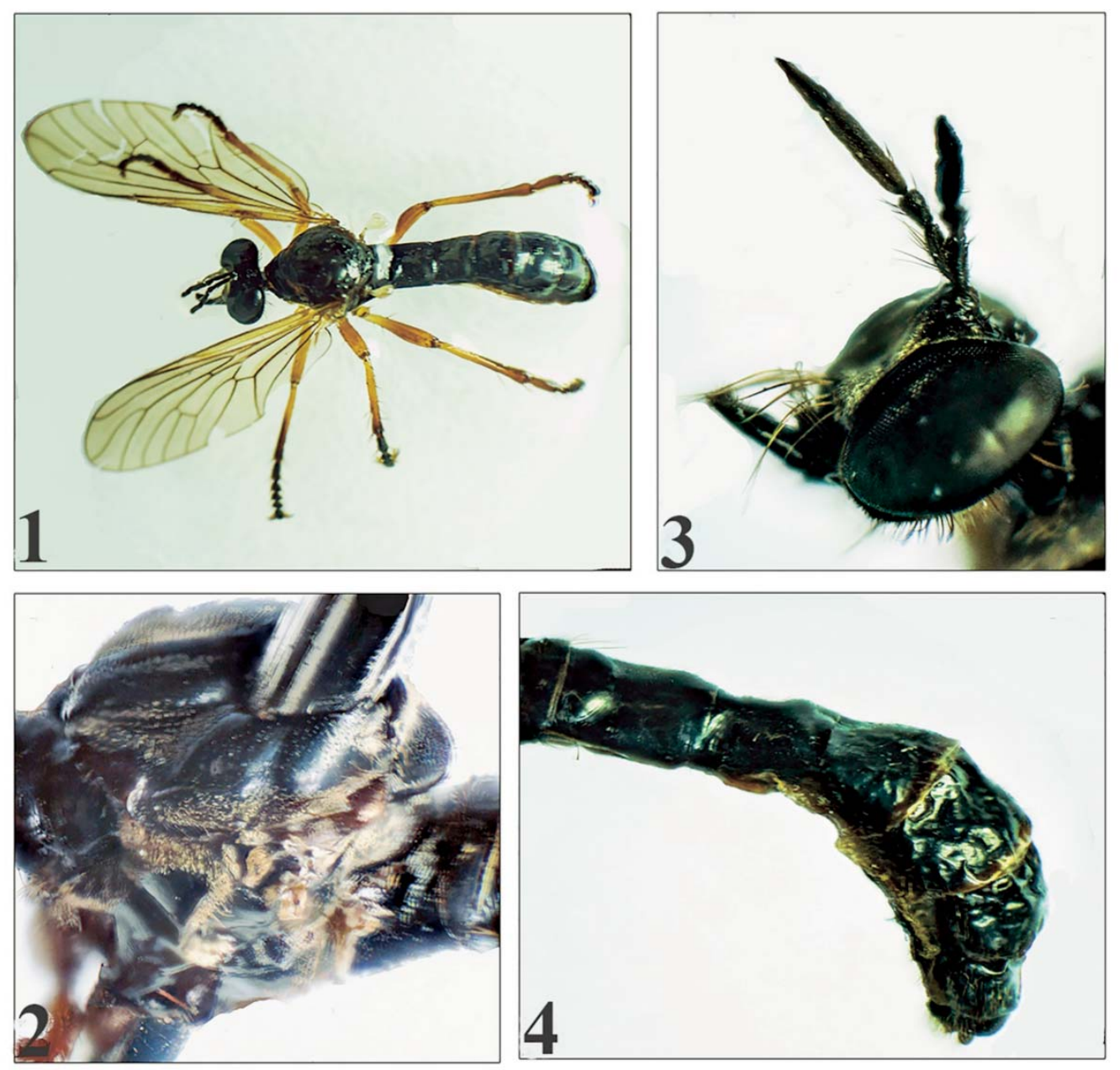

Fig. III - Dioctria humeralis Zeller, 1840 1-4: female. 1. General habitus, lateral view; 2. Thorax, lateral view; 3 . Head, lateral view; 4 . Abdomen, lateral view.

Dioctria hyalipennis (Fabricius, 1794)

Iranian records: Sistan \& Baluchestan province (HAYAT et al., 2008).

General distribution: Algeria, Austria, Belgium, Bulgaria, Canada, Czech Republic, Denmark, England, Finland, France, Great Britain, Italy, Luxembourg, Poland, Romania, Russia, Spain, Switzerland, The Netherlands, Tunisia, USA, former Yugoslavia (GELLER-GRIMM et al., 2015).

\section{Dioctria linearis (Fabricius, 1787)}

(Fig. IV, 1-3)

Material examined: East Azarbaijan province, Arasbaran forests, 38 51'42" N, 46 $58^{\circ} 17^{\prime}$ ” E, $1568 \mathrm{~m}, 25$ May 2013, 1 ㅇ (photographed specimen); Ghurigol 37 $55^{\circ} 12^{\prime \prime} \mathrm{N}$, 4641'31" E, 1888 m, 22 July 2013, 1ㅇ, 1ㅊ; Hashtroud $37^{\circ} 31$ '10" N, 4651'13” E, $1682 \mathrm{~m}, 4$ August 2010, 1 ㅇ, $1{ }^{\circ}$.

Iranian records: Guilan province (HAYAT et al., 2008), East Azarbaijan province (current study).

General distribution: Austria, Belgium, Bulgaria, Czech Republic, Denmark, England, former Yugoslavia, France, Germany, Hungary, Italy, Luxembourg, The Netherlands, Poland, Romania, Russia, Switzerland (GELLER-GRIMM et al., 2015).

\section{Dioctria lugens Loew, 1873} Iranian records: Iran (no locality cited) (LEHR, 1988).

General distribution: Turkey (GELLER-GRIMm et al., 2015).

\section{Dioctria pilithorax Richter, 1960}

(Fig. V, 1-3)

Material examined: East Azarbaijan province, Arasbaran forests 38०51'32" N, 4659'42" E, 1783 m, 1 June 2013,

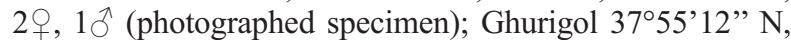
46 $41^{\prime} 31^{\prime \prime}$ E, 1888 m, 29 May 2012, 10'; Kandovan: 37 $46^{\prime} \mathrm{N}, 46^{\circ} 15^{\prime} \mathrm{E}, 2341 \mathrm{~m}, 23$ June 2015, 2 ㅇ.

Iranian records: East Azarbaijan province (Current study), new record for Iran.

General distribution: Azerbaijan (LEHR, 1988).

Diagnostic characters: Rather small, black species (10 $\mathrm{mm}$ ). Mystax black in both sexes (Fig. V, 2). Frontal tubercle large, as high as length of pedicel; scape about $1.5 \mathrm{x}$ pedicel (Fig. V, 2). Thorax black, scutum with remarkably erect black setae (Fig. V, 3); stripe of pale tomentum on pleura dorsally widely interrupted; coxae black. Legs entirely black (Fig. V, 1). Wings largely 

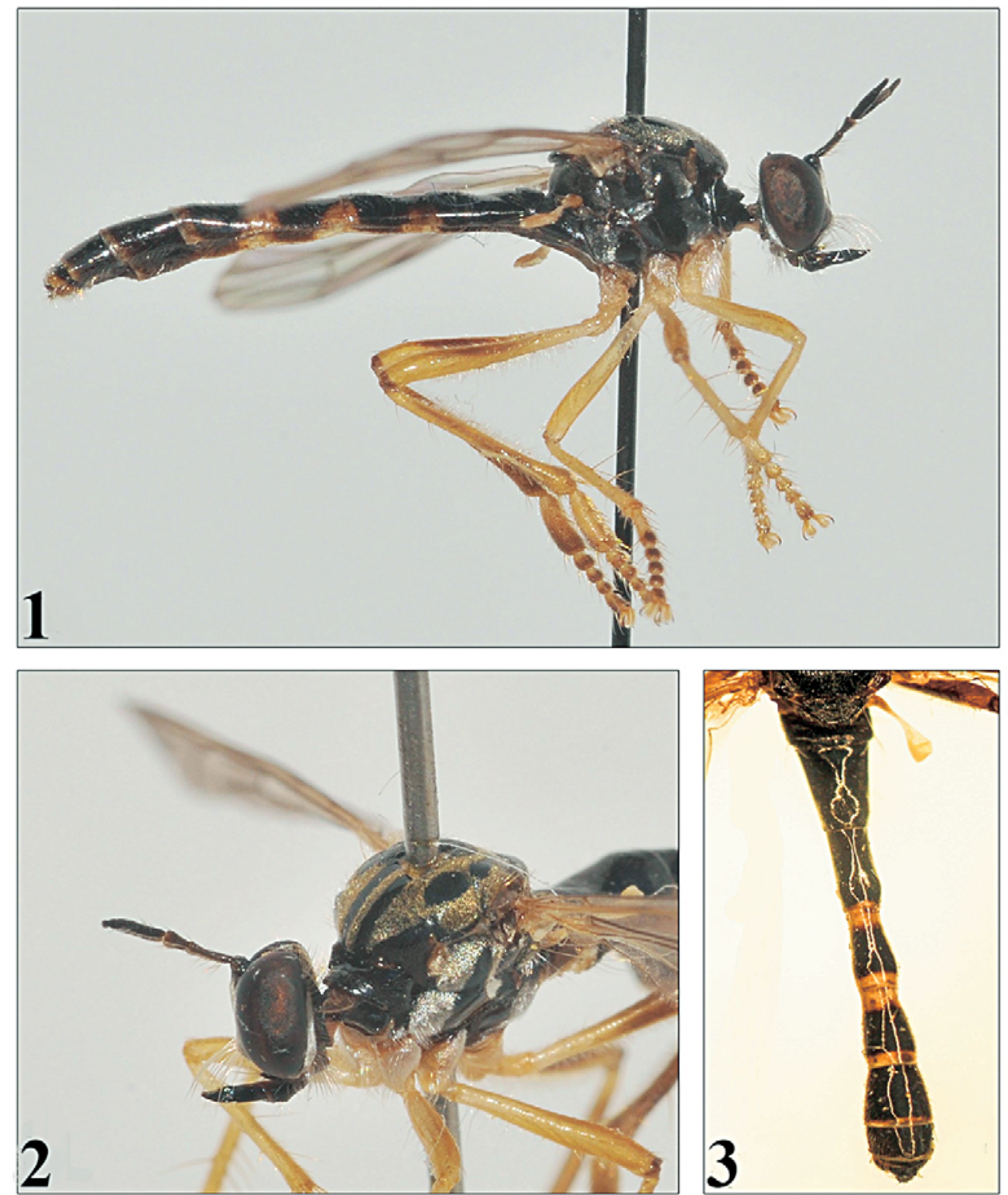

Fig. IV - Dioctria linearis (Fabricius, 1787) 1-3: female. 1. General habitus, lateral view; 2. Thorax, laterofrontal; 3. Abdomen, dorsal view.

infused with black microtrichia, apex lighter in males, apical half lighter in females (Fig. V, 1). Abdomen shiny black (Fig. V, 1).

Dioctria rufonigra Theodor, 1980

Iranian records: Mazandaran province (LEHR et al., 2007).

General distribution: Israel, Palestine, Turkey (GeLLERGRIMM et al., 2015).

Dioctria speculifrons Wiedemann, 1820

(Fig. VI, 1-4)

Material examined: Guilan province (Roodsar, Rahim abad, Ghazichak), 36 $45^{\prime} 57.54^{\prime \prime}$ N, 50 $0^{\circ} 19^{\prime} 35.22^{\prime \prime}$ E, 1803 m, 3 August 2010, $2 \delta^{\lambda}$ (photographed specimen); Guilan province (Roodsar, Rahim abad, Orkom), 36 $45^{\prime} 44.34^{\prime \prime} \mathrm{N}$, $50^{\circ} 18^{\prime} 11.88^{\prime \prime}$ E, $1201 \mathrm{~m}, 16$ August 2010, 30^; Alborz

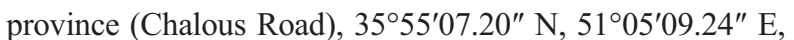
$1891 \mathrm{~m}, 5$ July 2010, 2 §.

Iranian records: Alborz and Guilan provinces (current study), new record for Iran.

General distribution: Armenia, Azerbaijan, Georgia, Spain, Portugal (Lehr, 1988; Geller-Grimm et al., 2015).

Diagnostic characters: A smaller sized $(7-10 \mathrm{~mm})$, black Dioctria species with a dark face. Shiny facial tomentum blackish, mystax black (Fig. VI, 2). Frontal tubercle about half as high as length of pedicel. Thorax black, scutum with distinct pattern of yellowish-brown tomentum leaving the two para median stripes and the lateral spots shiny black; Stripe of pale tomentum on pleura complete and brownish (Fig. VI, 3); coxae black. Legs black, only knees of legs sometimes light coloured (Fig. VI, 1). Wings hyaline (Fig. VI, 1). Abdomen shiny black (Fig. VI, 4). 

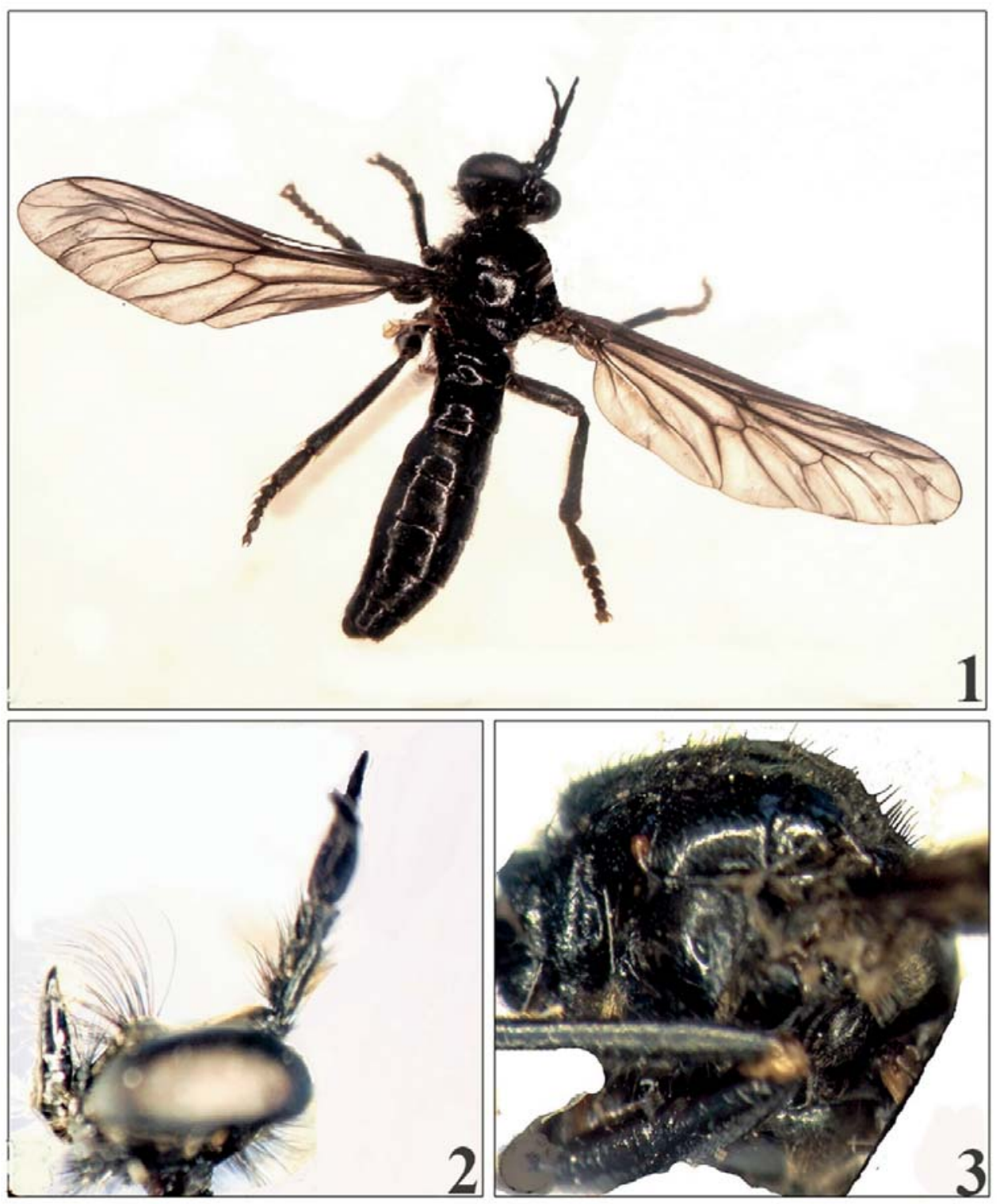

Fig. V - Dioctria pilithorax Richter, 1960 1-3: female. 1. General habitus, dorsal view; 2. Head, lateral view; 3 . Thorax, lateral view.

Dioctria striata Theodor, 1980

Iranian records: Fars, Kerman (LEHR et al., 2007).

General distribution: Israel, Palestine, Turkey (GELLERGRIMM et al., 2015).

Dioctria valida Loew, 1856

Iranian records: Isfahan province (LEHR et al., 2007).

General distribution: Israel, Lebanon, Palestine, Syria, Turkey (GELLER-GRIMM et al., 2015).

\section{KEY TO THE IRANIAN SPECIES OF THE GENUS DIOCTRIA}

This present and provisional key is based on ENGEL (1930), Richter (1988) and Geller-Grimm (2003). Important characters for the identification are the ratio of the antennal segments, especially the scape and the pedicel and a stripe of pale tomentum and pubescence on the side of the thorax. This stripe starts just above the front coxa, up to the dorsal side of the anepisternum and down again to just above the hind coxa (Fig. VII, 4). This stripe can be complete but in some species it is interrupted or partly absent.

1a. Thorax largely red or black with reddish brown parts (Fig. III, 2)

1b. Thorax black, at most a small red spot on humeral callus (Fig. I, 2; Fig. V, 3; Fig. VI, 3) ............................................................. 4

2a. Thorax largely reddish brown with a black median stripe on the scutum; abdomen black, lateral sides of tergite 2 and tergites 3-4 wholly reddish; wings blackened in anterior basal two thirds

D. rufonigra

2b. Only humeral and postalar calli red or brownish, sometimes also scutellum wholly or partly red; abdomen black ............................3

3a. Only humeral area brownish, rest of scutum shiny black with two broad stripes of tomentum bordering median bare stripe

3b. Both humeral and postalar calli and often part of scutellum 

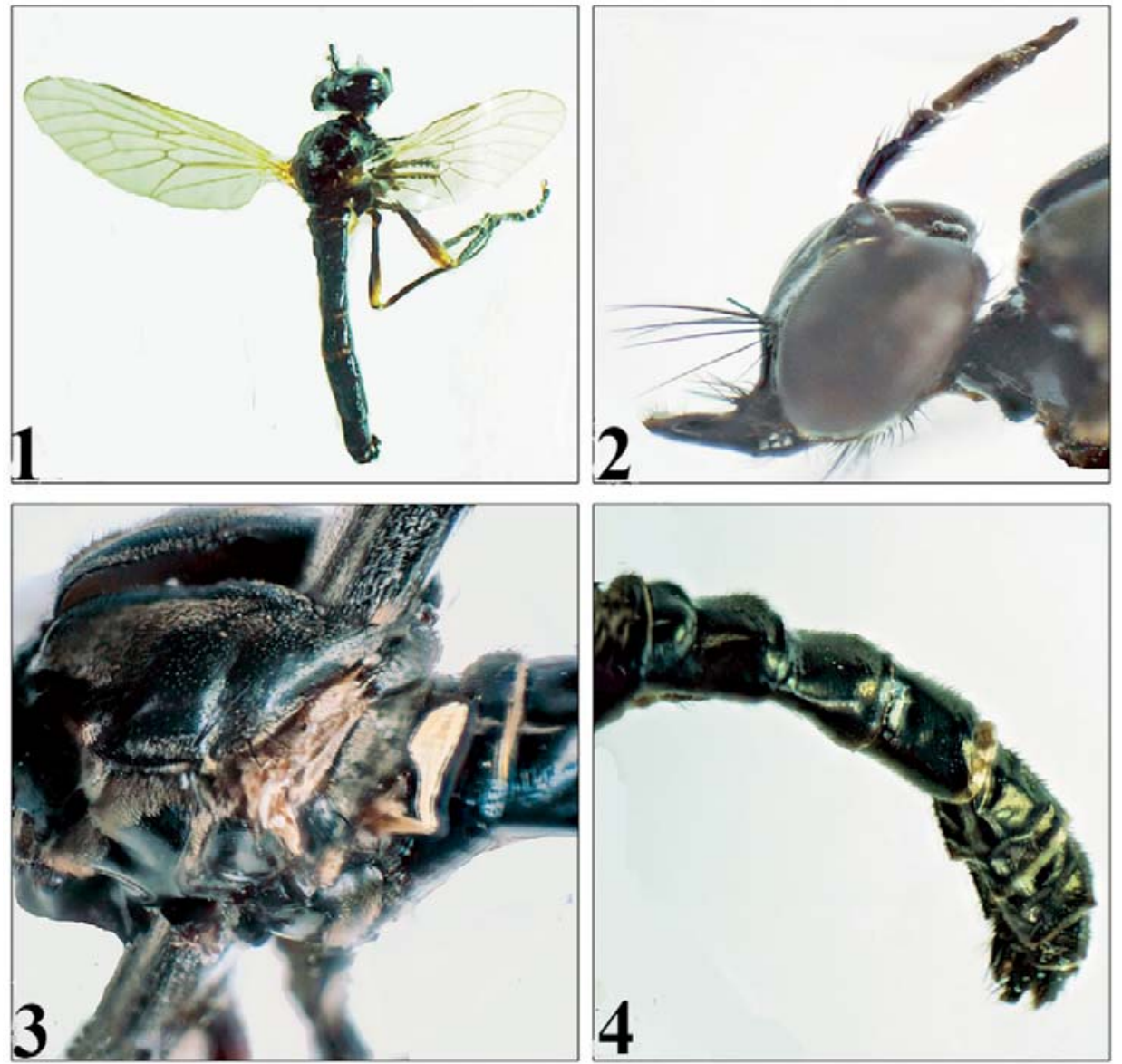

Fig. VI - Dioctria speculifrons Wiedemann, 1820 1-4: male. 1. General habitus, lateral view; 2. Head, lateral view; 3. Thorax, lateral view; 4. Abdomen, lateral view.

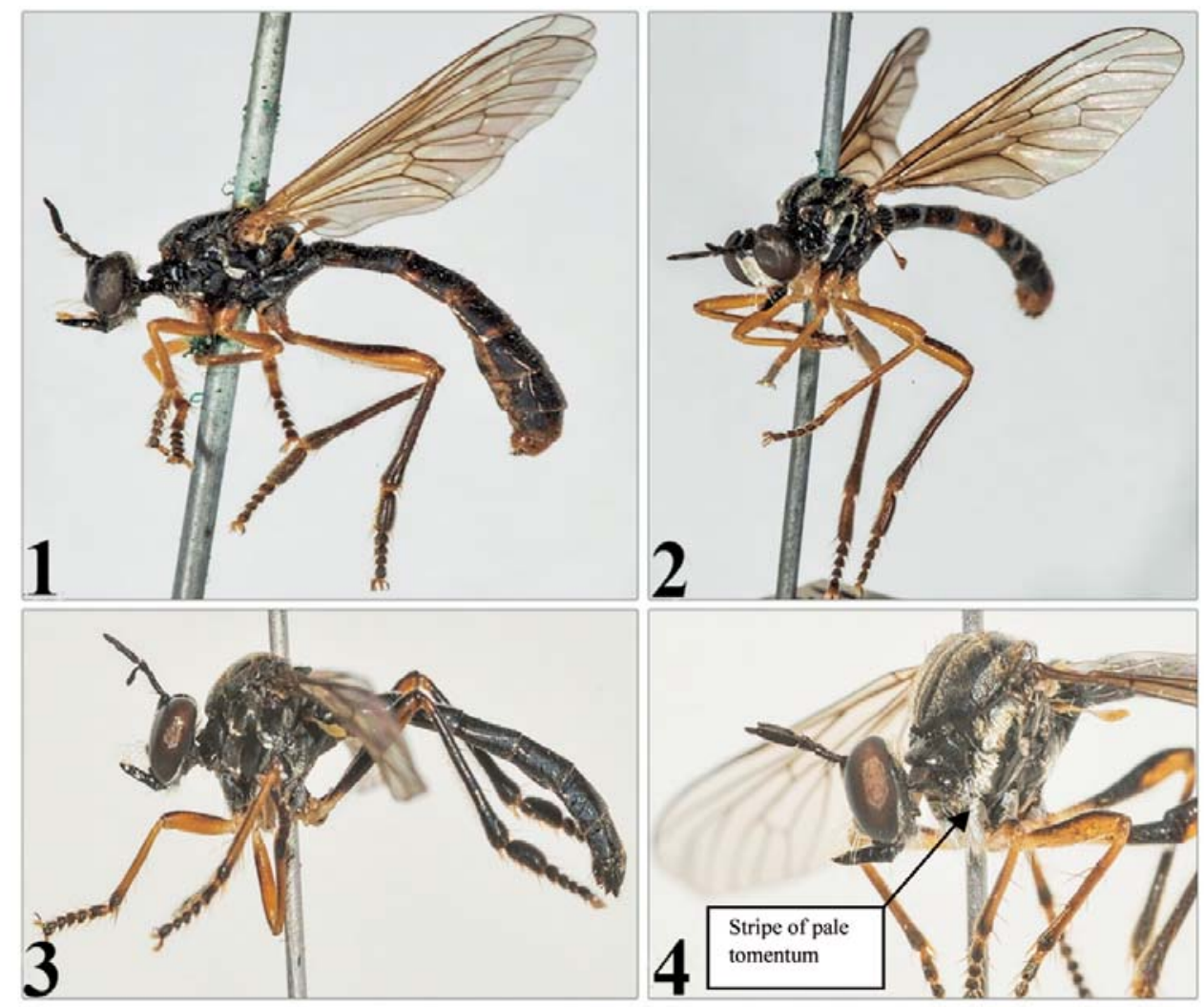

Fig. VII - Dioctria dispar Loew, 1871 1-2: male. 1. General habitus, lateral view; 2. General habitus, laterofrontal. Dioctria hyalipennis (Fabricius, 1794) 3-4: male: 3. General habitus, lateral view; 4. General habitus, laterofrontal. (Figs. 1 and 2 taken by Dr. Geller-Grimm). 
reddish, scutum with yellowish grey tomentum leaving two lines along medium stripe and the two connected lateral spots shiny black D. humeralis

4a. Scape equal to, or very slightly longer $(1 \mathrm{x}$ to $1.2 \mathrm{x})$ than pedicel

4b. Scape clearly longer (more than $1.4 \mathrm{x}$ ) than pedicel (Fig. I, 3; Fig. V, 2; Fig. VI, 2)

5a. Coxae yellow, front and middle legs yellow, tarsi darker, hind leg largely black ................................................................. gracilis

5b. Coxae black, all legs largely reddish yellow, tarsi brownish except last segment always yellow ........................................... D. valida

6a. Legs entirely or largely black (Fig. II, 1, 2)

6b. Legs largely yellow or red (Fig. I, 1; Fig. IV, 1)

, mees sometimes yellow or red; mystax black in

both sexes (Fig. VI, 2) ................................................ speculifrons

$7 \mathrm{~b}$. Wings largely or partly darkened; knees never yellow or red; mystax white or black

8a. Scutum covered with erect long black hairs (Fig. V, 3); mystax black in both sexes (Fig. V, 2) ....................................... D. pilithorax

8 b. Scutum with only very short hair in varying colour; mystax not black in both sexes .....

9a. Stripe of pale tomentum on pleura is brownish white and interrupted on dorsal side of anepisternum; parts of hind legs lighter coloured; mystax white in both sexes .................................... D. lugens

$9 \mathrm{~b}$. Brownish or yellowish stripe of pale tomentum on pleura complete (Fig. II, 2); hind legs not with lighter parts; mystax black in males, white in females ............................................... D. atricapilla

10a. Face with only tomentum on the lateral edges leaving a bare, vertical black stripe; mystax black (Fig. I, 3); wings darkened on anterior basal half (Fig. I, 5)

D. arnoldii

$10 \mathrm{~b}$. Face covered with shiny tomentum; mystax white or yellow; wings hyaline or anterior base coloured ............................................11

11a. Coxae black; abdomen black, at most posterior margins of tergites lighter in colour; scutum largely, but rather thinly covered with greyish tomentum leaving lines along median stripe and the lateral spots black; stripe of white tomentum on pleura complete with a thin additional stripe just above the middle coxa (Fig. VII, 3, 4)

D. hyalipennis

11b. Coxae yellow or brown; scutum with or without tomentum, the yellowish stripe of tomentum on pleura complete but without additional stripe

12a. Scutum somewhat shiny black and without tomentum; tergite 3 with a reddish brown band in the middle, tergite 4 and anterior part of tergite 5 reddish brown

D. abdominalis

$12 \mathrm{~b}$. Scutum black with a distinct pattern of tomentum; abdomen black or black with yellow lateral spots

13a. Tergites 3-5 black with light coloured posterior margins and yellow spots on the lateral sides (Fig. IV, 3); hind femur yellow with a dark spot on the anterior side that can be variable in size (Fig. IV, 1)

D. linearis

13b. Abdomen black, at most posterior margins lighter in colour;

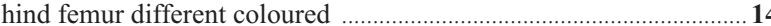

14a. All legs reddish yellow; base of wing somewhat brownish infuscate in male, yellowish in female ........................... D. flavipennis

14b. Legs largely reddish yellow, femur of the hind legs dorsally black, front tibia with darkened apex, middle tibia darkened with a lighter base, hind tibia black; basal half of wing in male darkened (Fig. VII, 2), in female wings almost hyaline (Fig. VII, 1) .............. D. dispar

\section{DISCUSSION}

The Asilidae are thermophilic predacious flies that mainly found in arid and semiarid areas of the planet (HuLL, 1962). Iran is located on the crossroad of three ecological zones, the Palearctic, Afrotropical and the Oriental (GHAHARI et al., 2014). Consequently, Iran harbors a rich vegetation as well as a rich insect fauna, including many species of robber flies (Diptera: Asilidae). Between 2008 and 2014 the number of species, including subspecies, of Asilidae recorded from Iran almost doubled from 156 (HAYAT et al., 2008) to 289 (GHAHARI et al., 2014). In many recent studies (MOHAMMADI and KHAGHANINIA, 2015, 2016; MOHAMMADI et al., 2017) including this study, more species are added. It seems that the study of Asilidae has long been neglected in Iran and many species can be expected in future studies in different parts of the country. With four new records of this study, the number of species of the genus Dioctria in Iran has increased to 15 . However, as many areas of Iran remain unexplored, we expect that the Dioctria fauna of Iran will be substantially increased.

\section{ACKNOWLEDGMENTS}

The authors would like to thank Dr. Dmitry Astakhov (Volgograd State University, Russia) and Dr. Jarsalov Bosak (Ecological Consulting a.s., Na Střelnici, Czech Republic) for their valuable help with the identification of the species and also we would like to thank Dr. Geller-Grimm (Museum Wiesbaden Natural History; Germany) for his help in producing photos of species previously reported from Iran but to which that we did not have access.

\section{REFERENCES}

Adisoemarto S., Wood D.M., 1975 - The Nearctic species of Dioctria and six related genera (Diptera, Asilidae). Quaest. entomol., 11: 505-576.

Dikow T., 2009 - Phylogeny of Asilidae inferred from morphological characters of imagines (Insecta: Diptera: Brachycera: Asiloidea). - Bull. Am. Mus. Nat. Hist., 319: 1-175.

Engel E.O., 1930 - Asilidae. In: Die Fliegen der Palaarktischen Region (ed. E. Lindner). Band IV(2) [9 parts: 1925-1930, complete book: 1938]. Stuttgart: Schweizerbart.

Ghahari H., Lehr P.A., Lavigne R.J., Hayat R., Ostovan H., 2007 - New records of robber flies (Diptera, Asilidae) for the Iranian fauna with their prey records. - Far. East. Entomol., 79: 1-9.

Ghahari H., HaYat R., LaVigne R.J., Ostovan H., 2014 An annotated checklist of Iranian Asilidae (Insecta: Diptera: Brachycera: Asiloidea). - Linzer biol. Beitr. 46 (2): 1379-1446.

GELLER-GRIMM F., 2003 - Identification key to the Dioctria species, Photographic atlas and identification key to the robber flies of Germany. Ampyx-Verlag, Halle (Saale), CD-ROM.

Geller-Grimm F., Dikow T., LAVIGne R.J. 2015 - Robber Flies (Asilidae) Database, Species. Available from: http://www.gellergrimm.de /catalog/species.htm (January 5, 2016)

Hayat R., Ghahari H., Lavigne R., Ostovan H., 2008 Iranian Asilidae (Insecta: Diptera). - Turk. J. Zool., 32: 175-195.

HuLL F.M., 1962 - Robber flies of the world: the genera of the family Asilidae. - U.S. Natl. Mus. Bull., 2: 556-558.

LEHR P.A., 1958 -K biologii $i$ znacheniyu ktyrei [Contribution to the biology and importance of robber flies (Asilidae - Diptera)]. - Tr. Inst. Zool. Akad. Nauk Kazakhskoi SSR, 8: 173-196. (In Russian). [English translation by Karriker \& Lavigne (transla 2) at http://www.geller grimm.de/catalog/transla.htm].

LeHR P.A., 1988 - Asilidae. In: Catalogue of Palearctic Diptera (eds. A. Soos, L. Papp). Elsevier Science Publishing Co. Inc. Amsterdam, pp. 197-326.

LEHR P.A., 2001 - Robber flies of the subfamily Dioctriinae stat. n. (Diptera, Asilidae) from Asia: 1. Taxonomy, ecology, and phylogeny [In Russian]. - Entomol. Obozr., 80(1): 194-208; [English: - Entomol. Rev., 81(1): 59-70; Moscow [Washington]. 
LEHR, P.A., 2002 - Robber flies of the subfamily Dioctriinae Hull from Asia: 2. Taxonomy and ecology [In Russian]. Entomol. Obozr., 82(2): 445-459, 526; [English: Entomol. Rev., 82(3): 797-808; St. Petersburg [Washington].

Lehr P.A., Ghahari H., Ostovan H., 2007 - A Contribution to the Robber Flies of Subfamilies Stenopogoninae and Asilinae (Diptera: Asilidae) from Iran. - Far. East. Entomol., 173: 1-14.

Mohammadi R., Khaghaninia S., 2015 - Flies of the subfamily Asilinae Latreille, 1802 (Diptera: Asilidae) in East Azerbaijan province, with three new records for Iranian Fauna. -Biharean biol., 10 (2): 79-81.

Mohammadi R., Khaghaninia S., 2016 - Family Asilidae (Diptera: Brachycera: Asiloidea) in East Azerbaijan province, with two new records for Iranian Fauna. - J. Insect Biodivers. Syst., 01(2): 125-132.

Mohammadi R., Khaghaninia S., Astakhov D., 2017 Study of the robber flies (Diptera: Asilidae) in East and West Azerbaijan provinces of Iran, with two new species records for the country. - J. Insect Biodivers. Syst., 03(3): 247-255.

Papavero N., 1973 - Studies of Asilidae (Diptera), Systematics and Evolution. I. A. Preliminary Classification in Subfamilies. - Arq. Zool. (Sao Paulo), 23: $217-$ 274.

Richter V.A., 1960 - New species of Robber-Flies (Diptera, Asilidae) from Transcaucasia. - Dokl. Akad. Nauk. armyan. SSR, 31(4): 245-249. [Russian to German]

RICHTER V.A., 1964 - New and little known species of Robber-Flies (Diptera, Asilidae) in the fauna of Transcausasia. - Dokl. Akad. Nauk. armyan. SSR, 38(1): 53-57. [Russian to German]

RichteR V.A., 1988 - Keys to the Insects of the European Part of the USSR. Volume V. Diptera and Siphonoptera. Part II. Smithsonian Institution Libraries and The National Science Foundation Washington, D.C. pp 779-819. 
12 - Blank Page 